Relations industrielles

Industrial Relations

\title{
Don J. Lofgren, Dangerous Premises: An Insider's View of OSHA Enforcement
}

\section{Michael D. Parsons}

Volume 46, numéro 1, 1991

URI : https://id.erudit.org/iderudit/050666ar

DOI : https://doi.org/10.7202/050666ar

Aller au sommaire du numéro

Éditeur(s)

Département des relations industrielles de l'Université Laval

ISSN

0034-379X (imprimé)

1703-8138 (numérique)

Découvrir la revue

Citer ce compte rendu

Parsons, M. D. (1991). Compte rendu de [Don J. Lofgren, Dangerous Premises: An Insider's View of OSHA Enforcement]. Relations industrielles / Industrial Relations, 46(1), 247-248. https://doi.org/10.7202/050666ar

Tous droits réservés (C Département des relations industrielles de l'Université Laval, 1991
Ce document est protégé par la loi sur le droit d'auteur. L'utilisation des services d'Érudit (y compris la reproduction) est assujettie à sa politique d'utilisation que vous pouvez consulter en ligne.

https://apropos.erudit.org/fr/usagers/politique-dutilisation/ 
The institutionalisation of conflict resolution mechanisms is highly appropriate but it may lead to the unnecessary rigidity which itself would originate dissatisfaction. For example, wild strikes may occur when workers feel abandoned not only by management (their natural "enemy") but also by trade unions which are supposed to represent their interests. Quite often managers develop on their own informal bargaining with the subordinates that may be actually a convenient addition to the formal arrangements.

Formal order introduces rigidity that may be, substantially alienating and in this respect it defeats its original purpose. "Both the strategy of formalisation and the specific mechanisms chosen to achieve it are sucked into the struggle for control" (p. 114). There is always an open question to what extent, and under which circumstances, a given conflict may become solved by formalisation and institutionalisation. There are several cases in which it is actually impossible to unload the growing tension and to find reasonable solutions without changing the whole configuration of a given situation, for example by deposing a given manager.

Management people already now constitute a considerable social category even if they are much diversified and actually collective consciousness of them remains weak. It is quite difficult to find common interests between the bottom of the managerial hierarchy and the top as long as there is no any dramatic confrontation between management and labour that would integrate both sides. Definitely, the modern management has inherited much of the interests and outlooks of the traditional owners and controllers, but with the growing anonimity of capital (ownership of wealth without appreciable control, and control of wealth without appreciable ownership) managers gain a new identity founded on a considerable autonomy, privileges, service functions (service class), ability to defend themselves against any encroachments on their power and influence, as well as the specific professional formation (management schools, managerial consulting).

The organizational concentration reinforces the power of top management and this is not limited to the market economy. For example, in postcommunist Poland 100 largest enterprises control $38 \%$ of sales and $22 \%$ of employment (the same data for 500 largest enterprises are $66 \%$ and $49 \%$ ). Under communist rule in Poland every second member of the ruling party was a manager, and the political appointees constituted over $90 \%$ of all managers. It is an open question how much managers are able to reinforce their relative position in society in the period of postauthoritarian democratization. In Poland they are liberated from the dictate of the communist party, which does not exist any more, but they have to deal with strong trade unions, as well as with the self-governmental bodies. In present day Eastern Europe new managerial posts are advertised and the candidates apply for them on the basis of competition.

Alexander J. MATEJKO

University of Alberta

Dangerous Premises: An Insiders View of OSHA Enforcement, by Don J. LOFgren, Ithaca, N.Y., ILR Press, 1989, 244 p., ISBN 0-87546-150-6 (pbk.).

Lofgren's Dangerous Premises joins Berman's Death on the Job, Page and O'Brien's Bitter Wages, and Scott's Muscle and Blood as an expose of government inaction, foot dragging, and cover-up of health and safety threats in US workplaces. What distinguishes this effort is that it is the first book which presents a view of government regulation and enforcement of occupational health and safety from the perspective of an OSHA inspector. The body of the text is grounded in Lofgren's experiences as a California OSHA health inspector from the early to mid-1980's. 
Like a number of earlier books on occupational health and safety, this one is divided around serious health hazards. Lofgren has selected asbestos, carbon monoxide, formaldehyde, lead, noise, and solvents as his major focal points. Around each focal point, a narrative illustrating the problems and challenges of an OSHA health inspection is developed. In developing the inspection narratives, Lofgren makes an effort to explain the legal responsibilities, political pressures, and personal limitations an inspector must cope with whenever he/she begins to conduct a workplace inspection. He also explains what the inspector can and cannot do and what changes are needed to improve OSHA's performance.

While the first person narratives offer a unique perspective of OSHA regulation and enforcement activities, the book suffers from a number of serious flaws. One is the confusing use of OSHA to mean both state OSHA agencies and federal OSHA. The OSHAct provides a mechanism for the cration of federally monitored state OSHA plans. These state plans have conflicted with federal OSHA at times over the strictness of health and safety regulations. Indeed, federal OSHA once took legal action against California OSHA in an effort to force the state to lessen a health standard. Other state plans have been accused of being too lax in their enforcement efforts.

One is not certain at times whether Lofgren means federal OSHA, state OSHA, or both. The lack of specificity may not be a problem for US readers who are familiar with OSHA, but it is rather confusing for others. For international readers who are not well versed in the American federal system, the OSHA system as described by Lofgren is probably unfantomable.

A more serious shortcoming is the failure to go beyond a mere description of OSHA and offer some analysis of the US regulatory system in general or OSHA in particular. At the very least, Lofgren might have presented a framework for analysis which could have been used by the reader to better understand OSHA activities. Instead, the reader is presented with detailed narratives which give the "what" and "how", but not the "why" of the OSHA system.

A final flaw is the limited and isolated nature of Lofgren's recommendations for improving the OSHA system. It is here that the failure to provide a framework for analysis is most painfully evident as Lofgren is limited to mere "add ons" and tinkering with the current system on a surface level rather than addressing OSHA at a more fundamental level. The suggested changes and improvements have been presented by various authors over the past twenty years.

The suggested changes are isolated from experiences in other countries. American unions and some regulatory reformers have looked to selected Canadian provinces and Scandinavian countries in recent years for lessons which could be applied to the US OSHA system. Lofgren does not look to other countries, but instead limits his recommendations to what he experienced as a California OSHA health inspector and to traditional liberal reforms.

In summary, the book is a well written, easy to read account of an insider's view of the OSHA system. It is valuable because it is the first book which presents an inspector's perspective. Because of the flaws discussed above, the book will probably be of interest to more serious OSHA scholars rather than general readers.

Michael D. PARSONS

Indiana University 